\title{
Carbon Dioxide and Ocean Acidification
}

\author{
Peter Stallinga, PhD \\ University of the Algarve, FCT-DEEI and CEOT, Portugal
}

Doi: 10.19044/esj.2018.v14n18p476 URL:http://dx.doi.org/10.19044/esj.2018.v14n18p476

\begin{abstract}
One of the results of Anthropogenic Global Warming is the acidification of the oceans which threatens wildlife on this planet. In this work it will be shown what will be the effect of carbon dioxide injected into the atmosphere, doubling the total amount from $350 \mathrm{ppm}$ to $700 \mathrm{ppm}$. Principally the effect on carbonate ions $\mathrm{CO}_{3}{ }^{2-}$. It is based on textbook chemical principles worked out by numerically solving the resulting non-linear equations by the bisection method. The results are the following: In a pure-water environment the effect is that carbonate ion concentration remains unaltered (i.e., no harm to coral reefs). In a constant-pH environment the carbonate ion concentration grows linearly with $\mathrm{CO} 2$ in the atmosphere (i.e., good for coral reefs). When lowering the $\mathrm{pH}$ by other means than $\mathrm{CO}_{2}$, the carbonate ion concentration drops linearly (i.e., bad for coral reefs). In some specific cases can raising the $\mathrm{CO}_{2}$ in the atmosphere slightly reduce carbonate ions in the oceans.
\end{abstract}

Keywords: Ocean acidification, coral reefs, Le Châtelier

\section{Introduction}

A search in the Web of Knowledge results in nearly five thousand hits on "acidification of the oceans". It is a concept that apparently worries the scientific and political communities alike. When the acidity of the oceans increases, so the idea goes, wild life in the oceans will suffer or even die (Silverman, Lazar, Cao, Caldeira, and Erez, 2009). An example is the starving of coral reefs by the depletion of their primary construction material, carbonate ions $\mathrm{CO}_{3}{ }^{2-}$, used for making their exoskeletons (Hoegh-Guldberg et al., 2007; Kleypas et al., 1999). Newspapers alarmingly report of "bleaching of the coral reefs". As stewards of this planet we have the responsibility to take good care of all life on this planet, including in the seas. As such, we cannot allow entire species to be at risk of extermination because of our human behavior. It has been said that it is our behavior, through the production of carbon dioxide by burning fossil fuels, that causes this increase in acidity of the oceans and the mass death of species within them (Royal Society, 2005).

Knowing that media tend to exaggerate, we can do our own research. 
A small study learns that oceans, in fact, are not acidic, but basic. Indeed, the $\mathrm{pH}$ of the oceans is about 8.14 (Jacobson, 2005), which is slightly basic. However, the same paper of Jacobson mentions that it has dropped from 8.25 and this is attributed to the increase of $\mathrm{CO}_{2}$ in the atmosphere that is absorbed by the oceans. Therefore, it might well be that in the future the $\mathrm{pH}$ drops below 7 and the oceans turn acidic. In any case, depriving sea life of the necessary ingredient of $\mathrm{CO}_{3}{ }^{2-}$ cannot be beneficial.

Many studies mention the negative effect of $\mathrm{CO}_{2}$ on sea life. All these studies make a logical error, namely this: $\mathrm{CO}_{2}$ lowers the $\mathrm{pH}$ of the oceans. A lower $\mathrm{pH}$ is bad for sea life. Therefore, $\mathrm{CO}_{2}$ is bad for sea life. As an example, Ware reports that "... it frequently has been thought that coral reefs function as sinks of global atmospheric $\mathrm{CO}_{2}$. However, the precipitation of calcium carbonate is accompanied by a shift of $\mathrm{pH}$ that results in the release of $\mathrm{CO}_{2}$ "'(Ware, Smith, and Reaka-Kudla, 1991). Similar conclusions are reached by Michaelis. NOAA summarizes his work as: "Specimens of Mytilus galloprovincialis that were maintained for three months at $\mathrm{pH}=7.3$ (consistent with a $\mathrm{pCO}_{2}$ of about $1900 \mu \mathrm{atm}$ ) experienced significant reduction in growth, as well as shell dissolution, in response to reduced haemolymph bicarbonate levels". Michaelidis writes in the abstract of his paper "The results obtained in the present study strongly indicate that a reduction in sea-water $\mathrm{pH}$ to 7.3 may be fatal for the mussels." (Michaelidis, Ouzounis, Paleras, and Pörtner, 2005). Similarly, the (self acclaimed) authority on Climate Change, the IPCC, writes in its Fourth Assessment Report, "Increasing atmospheric $\mathrm{CO}_{2}$ concentrations lower oceanic $\mathrm{pH}$ and carbonate ion concentrations, thereby decreasing the saturation state with respect to calcium carbonate" (Solomon et al., 2007). Without giving more examples, it is obvious that this is the consensus in literature. For completeness' sake, we also point out here that there are other explanations given for coral bleaching, namely the rise of ocean temperatures. See for instance the work of Hoegh-Guldberg (Hoegh-Guldberg, 1999). (Without going into detail, we are critical of such conclusions, since coral reefs exist in a wide variety of temperatures, and are moreover concentrated in the warmer zones of our planet. Wikipedia: "Although corals exist both in temperate and tropical waters, shallow-water reefs form only in a zone extending from approximately $30^{\circ} \mathrm{N}$ to $30^{\circ} \mathrm{S}$ of the equator." Warming of our planet would therefore seem beneficial for coral reefs, which leaves us with the ocean acidification to explain the observed data).

In this work we study the effect of $\mathrm{CO}_{2}$ on $\mathrm{CO}_{3}{ }^{2-}$ and will show that the effects of increments of atmospheric $\mathrm{CO}_{2}$ range from no effect (in a clean water environment) to a linear increase of the concentration of $\mathrm{CO}_{3}{ }^{2-}$ in the ocean (in a more realistic constant-pH basic environment). In special cases $\mathrm{CO}_{2}$ can reduce the amount of $\mathrm{CO}_{3}{ }^{2-}$ in the oceans. 


\section{Results and discussion:}

All chemical equations are equilibrium equations of the type

$$
m \mathrm{~A}+n \mathrm{~B} \ldots \rightleftharpoons p \mathrm{X}+q \mathrm{Y} \ldots,
$$

the equilibrium constant of which is given by

$$
K=\frac{[\mathrm{X}]^{p}[\mathrm{Y}]^{q}}{[\mathrm{~A}]^{m}[\mathrm{~B}]^{n}}
$$

where the square brackets indicate the concentration of the reactant enclosed in the brackets. The important thing is that, because the equilibrium reaction constant is indeed constant, adding a reactant on one side of the reaction will drive the reaction towards the other side. This is Le Châtelier's principle. As an example, if we increase the concentration of $\mathrm{A}$ in the above reaction, [B] will decrease, and $[\mathrm{X}]$ and $[\mathrm{Y}]$ will increase until the equilibrium ratio as given in Eq. (2) is restored. In no way can adding reactants on one side of the reaction drive the reaction towards that side of the reaction.

The chemistry of carbon dioxide is quite complex, but it boils down to reactions as in Eq. (1). In the first step, $\mathrm{CO}_{2}$ of the atmosphere dissolves into the ocean

$$
\mathrm{CO}_{2}(\mathrm{~g}) \rightleftharpoons \mathrm{CO}_{2}(\mathrm{aq})
$$

In water the $\mathrm{CO}_{2}$ molecules combine with water molecules to form $\mathrm{H}_{2} \mathrm{CO}_{3}$, and this reaction can be written as

$$
\mathrm{CO}_{2}(\mathrm{aq})+\mathrm{H}_{2} \mathrm{O}(\mathrm{l}) \rightleftharpoons \mathrm{H}_{2} \mathrm{CO}_{3}(\mathrm{aq}) .
$$

Here the ratio of the two concentrations of Eq. (I) is given by Henry's Constant, that depends on the temperature (see Table 6-7 of Lide and Frederikse (1974)),

$$
K_{\mathrm{h}}(T)=\frac{\left[\mathrm{CO}_{2}(\mathrm{~g})\right]}{\left[\mathrm{CO}_{2}(\mathrm{aq})\right]} .
$$

In ice core data we can recognize that the $\mathrm{CO}_{2}$ gas in the atmosphere lags behind the temperature of the atmosphere by about 700 years (Indermühle, Monnin, Stauffer, Stocker, and Wahlen, 2000). The above ratio also implies that when we inject carbon dioxide into the atmosphere, most of it will wind up in the oceans. It is estimated that about $95 \%$ of anthropogenic (or other) carbon dioxide winds up in the oceans and that the residence time of the carbon dioxide in the atmosphere is less than a decade (Essenhigh, 2009; Starr, 1992). Moreover, recent El Niño warming of the oceans caused a serious out-gassing of dissolved carbon dioxide.

Henceforward all reactants are in water, so we omit the designation '(aq)' from now on. In the second step, the dissolved carbon dioxide reacts in an acid-base reaction with water to form bicarbonate ions and protons,

$$
\mathrm{H}_{2} \mathrm{CO}_{3} \rightleftharpoons \mathrm{HCO}_{3}^{-}+\mathrm{H}^{+} \text {. }
$$

Such reactions are of the general acid-base reaction form of Table 8-43 of Lide and Frederikse (1974), 


$$
\mathrm{HB} \rightleftharpoons \mathrm{B}^{-}+\mathrm{H}^{+},
$$

where $\mathrm{HB}$ is a generic acid that dissociates into the $\mathrm{B}^{-}$conjugate base of the acid and a hydrogen ion $\mathrm{H}^{+}$which combines with a water molecule to make a hydronium ion $\mathrm{H}_{3} \mathrm{O}^{+}$. The reaction is characterized by the acid dissociation constant, or $\mathrm{p} K_{\mathrm{a}}$ value

in this case

$$
K_{\mathrm{a}}=\frac{\left[\mathrm{B}^{-}\right]\left[\mathrm{H}^{+}\right]}{[\mathrm{HB}]}(\mathrm{mol} / \mathrm{L}), \mathrm{p} K_{\mathrm{a}} \equiv-\log _{10}\left(\frac{K_{\mathrm{a}}}{1 \mathrm{~mol} / \mathrm{L}}\right),
$$

$$
K_{\mathrm{a} 1}=\frac{\left[\mathrm{HCO}_{3}^{-}\right]\left[\mathrm{H}^{+}\right]}{\left[\mathrm{H}_{2} \mathrm{CO}_{3}\right]}=4.47 \times 10^{-7} \mathrm{~mol} / \mathrm{L}, \mathrm{p} K_{\mathrm{a}}=6.35 .
$$

(The value at $25^{\circ} \mathrm{C}$ from Table 8-43 of Lide and Frederikse (1974)). This bicarbonate further reacts with water to form carbonate ions and another proton,

$$
\mathrm{HCO}_{3}^{-} \rightleftharpoons \mathrm{CO}_{3}^{2-}+\mathrm{H}^{+}
$$

with an acid dissociation constant given by [10]

$$
K_{\mathrm{a} 2}=\frac{\left[\mathrm{CO}_{3}^{2-}\right]\left[\mathrm{H}^{+}\right]}{\left[\mathrm{HCO}_{3}^{-}\right]}=4.68 \times 10^{-11} \mathrm{~mol} / \mathrm{L}, \mathrm{p} K_{\mathrm{a}}=10.33 .
$$

Finally, the carbonate ions react with calcium ions dissolved in water to form solid calcium carbonate,

$$
\mathrm{Ca}^{2+}+\mathrm{CO}_{3}^{2-} \rightleftharpoons \mathrm{CaCO}_{3}(\mathrm{~s})
$$

which is the basic ingredient of seashells and corals.

Indeed, if $\mathrm{CO}_{2}$ is added to the atmosphere, it will dissolve into the ocean and turn the water acidic (or, to be more precise, less alkaline, since the $\mathrm{pH}$ of the oceans is around 8.1). In normal circumstances, Le Châtelier's principle tells us that decreasing the $\mathrm{pH}$ (increasing $\left[\mathrm{H}^{+}\right]$) would drive reaction (V) to the left, thus reducing $\left[\mathrm{CO}_{3}{ }^{2-}\right]$ and thus pulling reaction (VI) to the left too, reducing the amount of solid calcium carbonate, effectively dissolving an amount of shells and corals in the ocean, including shells and exoskeletons on the sea floor.

However, this is true only when the source of protons is other than $\mathrm{CO}_{2}$, since $\mathrm{CO}_{2}$ is exactly what is driving driving reaction (II), and thus reaction (III) and thus reaction (V) to the right and thus what increases the concentration of $\mathrm{CO}_{3}{ }^{2-}$ and the amount of shells. We thus conclude at this point that burning fossil fuels might, in fact, increase corals and sea shells in general. In other words, acid rain, when the acid is in the form of sulphuric or nitric acid, dissolves shells, while carbonic-acid rain does not necessarily dissolve them.

Some researchers, for instance NOAA at their home pages (NOAA, 2017), give a calcium-carbonate destroying reaction, 
claiming that adding $\mathrm{CO}_{2}$ to the water will consume carbonate ions, as per the reaction

$$
\mathrm{H}_{2} \mathrm{CO}_{3}+\mathrm{CO}_{3}^{2-} \rightleftharpoons 2 \mathrm{HCO}_{3}^{-},
$$

an acid-base reaction with a single proton hopping from one molecule to the other. The dimensionless reaction constant is given by

$$
K_{\mathrm{a} 3}=\frac{\left[\mathrm{HCO}_{3}^{-}\right]^{2}}{\left[\mathrm{H}_{2} \mathrm{CO}_{3}\right]\left[\mathrm{CO}_{3}^{2-}\right]} \text {. }
$$

Indeed if only $\mathrm{CO}_{2}$ (that is, $\mathrm{H}_{2} \mathrm{CO}_{3}$ ) is added on the left side of reaction (VII), the reaction will be driven to the right and consume $\mathrm{CO}_{3}{ }^{2-}$. However, as we have seen in reaction (III), adding $\mathrm{CO}_{2}$ in fact also increases the $\mathrm{HCO}_{3}{ }^{-}$concentration and thus, according to Le Châtelier's principle, the reaction might be driven to the left! Adding $\mathrm{CO}_{2}$ will not deplete $\mathrm{CO}_{3}{ }^{2-}$, but can even increase it and this will enable growth of corals and shells (if there is enough calcium dissolved in the oceans).

The reaction constant $K_{\mathrm{a} 3}$ cannot be found in literature, but it can easily be expressed in terms of the other two acid dissociation constants. Combining Eqs. (5) and (6) we find

$$
K_{\mathrm{a} 3}=\frac{K_{\mathrm{a} 1}}{K_{\mathrm{a} 2}}=9.55 \times 10^{3} .
$$

Before we start our calculations, we need to add one more reaction. Water is also an acid-base dissociation reaction, or self-ionization reaction,

$$
\mathrm{H}_{2} \mathrm{O} \rightleftharpoons \mathrm{H}^{+}+\mathrm{OH}^{-},
$$

with the reaction governed by the constant

implying

$$
K_{\mathrm{w}}=\left[\mathrm{H}^{+}\right]\left[\mathrm{OH}^{-}\right]=1.0 \times 10^{-14}(\mathrm{~mol} / \mathrm{L})^{2},
$$

$$
\left[\mathrm{OH}^{-}\right]=\frac{10^{-14}(\mathrm{~mol} / \mathrm{L})^{2}}{\left[\mathrm{H}^{+}\right]}
$$

We have now all ingredients to reason and calculate what will happen when increasing carbon dioxide in the atmosphere. We get one additional condition that the total amount of positive charge must be equal to the total amount of negative charge,

$$
\left[\mathrm{H}^{+}\right]=\left[\mathrm{HCO}_{3}^{-}\right]+2 \times\left[\mathrm{CO}_{3}^{2-}\right]+\left[\mathrm{OH}^{-}\right] \text {. }
$$

These equations imply that the effect of doubling $\mathrm{CO}_{2}$ in the atmosphere on the concentration of $\mathrm{CO}_{3}{ }^{2-}$ in these oceans is minimal. That the effect is minimal is clear once we understand that in the first acid-base reaction, (III), the concentrations of $\left[\mathrm{HCO}_{3}{ }^{-}\right]$and $\left[\mathrm{H}^{+}\right]$are nearly equal (since the second acid-base reaction, (V), does not produce much $\mathrm{H}^{+}$). Doubling $\left[\mathrm{H}_{2} \mathrm{CO}_{3}\right]$ will thus mean that $\left[\mathrm{HCO}_{3}{ }^{-}\right]$ and $\left[\mathrm{H}^{+}\right]$are multiplied by the square root of 2 . In the second acid- 
base reaction, $(\mathrm{V})$, they then cancel each other out, and $\left[\mathrm{CO}_{3}{ }^{2-}\right]$ remains unaltered, $\left[\mathrm{CO}_{3}{ }^{2-}\right] \approx K_{\mathrm{a} 2}$.

We can even give numerical examples of some specific cases, what will be done now. We start with the observation that it is more common to express the gas-phase $\mathrm{CO}_{2}$ in terms of partial pressure, see for instance Table 6-7 of Lide and Frederikse (1974). As an example, at $25^{\circ} \mathrm{C}$ at $5 \mathrm{kPa}$ partial pressure of $\mathrm{CO}_{2}$ in the atmosphere (about 5 parts per 100), the equilibrium concentration is $3.1 \times 10^{-6}$ mole fraction $\mathrm{CO}_{2}$ in the water. At $350 \mathrm{ppm}$ it is then $2.17 \times 10^{-8}$ mole fraction. With 55.55 moles $\mathrm{H}_{2} \mathrm{O}$ in a liter of water, the $\mathrm{CO}_{2}$ concentration in water (at 25 degrees) below this 350-ppm atmosphere is

$$
\text { at } 350 \text { ppm: }\left[\mathrm{H}_{2} \mathrm{CO}_{3}\right]=1.2 \times 10^{-5} \mathrm{~mol} / \mathrm{L} \text {. }
$$

Combining Equations (5), (6), (10), (11) and (12) we find

$$
\begin{gathered}
{\left[\mathrm{HCO}_{3}^{-}\right]=\left[\mathrm{H}^{+}\right]=2.32 \times 10^{-6} \mathrm{~mol} / \mathrm{L}(\mathrm{pH}=5.63),} \\
\text { at } 350 \mathrm{ppm}:\left[\mathrm{CO}_{3}^{2-}\right]=4.67 \times 10^{-11} \mathrm{~mol} / \mathrm{L} .
\end{gathered}
$$

(These results were found by solving a third-degree polynomial equation by means of the bisection method (Press, 1989)). If we now double the amount of $\mathrm{CO}_{2}$ in the atmosphere and repeat the calculations, we get

$$
\begin{gathered}
{\left[\mathrm{H}_{2} \mathrm{CO}_{3}\right]=2.4 \times 10^{-5} \mathrm{~mol} / \mathrm{L},} \\
{\left[\mathrm{HCO}_{3}^{-}\right]=\left[\mathrm{H}^{+}\right]=3.28 \times 10^{-6} \mathrm{~mol} / \mathrm{L}(\mathrm{pH}=5.48),} \\
\text { at } 700 \mathrm{ppm}:\left[\mathrm{CO}_{3}^{2-}\right]=4.68 \times 10^{-11} \mathrm{~mol} / \mathrm{L} .
\end{gathered}
$$

Sea life will barely notice what is happening in the atmosphere.

\section{$\log \left(\left[\mathrm{CO}_{2}(\mathrm{~g})\right]\right)$}

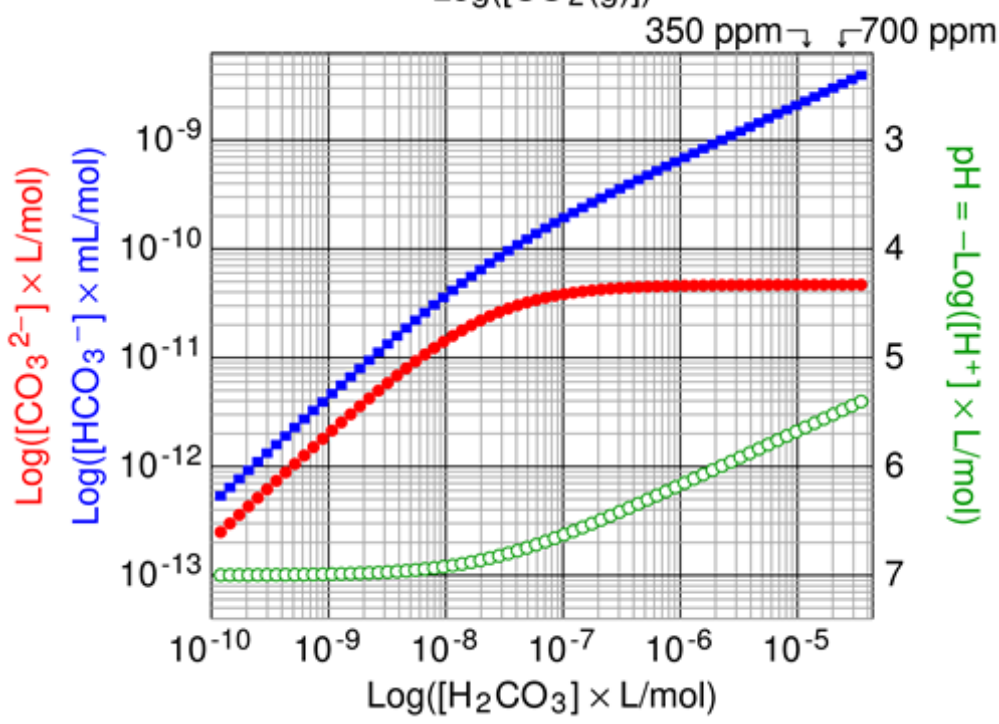

Figure 1: Concentration of carbonate ions ( $\bullet$ red full circles) bicarbonate ions ( $\square$ blue squares, 1000x scale) and $\mathrm{pH}$ ( $\circ$ green open circles) as a function of concentration of $\mathrm{CO}_{2}$ in the oceans and air. 
Figure 1 gives a summary of the effect that adding $\mathrm{CO}_{2}$ in the atmosphere has on the $\mathrm{pH}$ and concentration of $\mathrm{CO}_{3}{ }^{2-}$ in the oceans when we start with clean water. We see that the bicarbonate ion concentration indeed levels off at $\left[\mathrm{CO}_{3}{ }^{2-}\right]=K_{2}=4.68 \times 10^{-11} \mathrm{~mol} / \mathrm{L}$.

Let's repeat the calculation for an environment that is closer to the one of the oceans, namely a basic environment with a constant $\mathrm{pH}$, kept constant by some unspecified buffer reaction. While the calculations can be done on basis of $\mathrm{H}^{+}$concentrations using the above equations, they are more elegant when we replace the acid-base reactions given above to the equivalent ones that involve hydroxide-ions,

$$
\mathrm{H}_{2} \mathrm{CO}_{3}+\mathrm{OH}^{-} \rightleftharpoons \mathrm{HCO}_{3}^{-}\left(+\mathrm{H}_{2} \mathrm{O}\right) \text {, }
$$

with a reaction constant given by

$$
K_{\mathrm{b} 1}=\frac{\left[\mathrm{H}_{2} \mathrm{CO}_{3}\right]\left[\mathrm{OH}^{-}\right]}{\left[\mathrm{HCO}_{3}^{-}\right]} .
$$

Given the fact that $\left[\mathrm{OH}^{-}\right]\left[\mathrm{H}^{+}\right]=K_{\mathrm{w}}$, this reaction constant is

$$
K_{\mathrm{b} 1}=\frac{K_{\mathrm{w}}}{K_{\mathrm{a} 1}}=2.24 \times 10^{-8} \mathrm{~mol} / \mathrm{L} \text {. }
$$

Likewise, the second acid-base reaction is replaced by

$$
\mathrm{HCO}_{3}^{-}+\mathrm{OH}^{-} \rightleftharpoons \mathrm{CO}_{3}^{2-}\left(+\mathrm{H}_{2} \mathrm{O}\right)
$$

with a reaction constant given by

$$
K_{\mathrm{b} 2}=\frac{\left[\mathrm{HCO}_{3}^{-}\right]\left[\mathrm{OH}^{-}\right]}{\left[\mathrm{CO}_{3}^{2-}\right]}=\frac{K_{\mathrm{w}}}{K_{\mathrm{a} 2}}=2.14 \times 10^{-4} \mathrm{~mol} / \mathrm{L} .
$$

If we have a buffered basic environment, both hydronium and hydroxide concentrations $\left(\left[\mathrm{H}^{+}\right]\right.$and $\left.\left[\mathrm{OH}^{-}\right]\right)$are constant. At this moment the buffer itself is irrelevant; what matters is that some phenomena is keeping the $\mathrm{pH}$ constant. Note that the charge neutrality equation (Eq. 11) is maintained by the production or annihilation of the conjugate base.

We can then easily see that any factor in increase in the concentration of carbon dioxide in the atmosphere will cause an equal factor in the increase of $\left[\mathrm{CO}_{3}{ }^{2-}\right]$ in the oceans. In fact,

$$
\left[\mathrm{CO}_{3}^{2-}\right]=\frac{\left[\mathrm{H}_{2} \mathrm{CO}_{3}\right]\left[\mathrm{OH}^{-}\right]^{2}}{K_{\mathrm{b} 1} K_{\mathrm{b} 2}}
$$

Taking a typical value of a $\mathrm{pH}$ of $8.1\left(\left[\mathrm{OH}^{-}\right]=1.26 \times 10^{-6} \mathrm{~mol} / \mathrm{L}\right)$, we find that for a $350 \mathrm{ppm}$ atmosphere $\left(\left[\mathrm{H}_{2} \mathrm{CO}_{3}\right]=1.2 \times 10^{-5} \mathrm{~mol} / \mathrm{L}\right)$,

$$
\begin{gathered}
{\left[\mathrm{HCO}_{3}^{-}\right]=6.75 \times 10^{-4} \mathrm{~mol} / \mathrm{L},} \\
\text { at } 350 \mathrm{ppm}:\left[\mathrm{CO}_{3}^{2-}\right]=3.98 \times 10^{-6} \mathrm{~mol} / \mathrm{L} .
\end{gathered}
$$

If we now double the amount of $\mathrm{CO}_{2}$ in the atmosphere and repeat the calculations, we get

$$
\begin{aligned}
& {\left[\mathrm{H}_{2} \mathrm{CO}_{3}\right]=2.4 \times 10^{-5} \mathrm{~mol} / \mathrm{L},} \\
& {\left[\mathrm{HCO}_{3}^{-}\right]=1.35 \times 10^{-3} \mathrm{~mol} / \mathrm{L},}
\end{aligned}
$$


at $700 \mathrm{ppm}:\left[\mathrm{CO}_{3}^{2-}\right]=7.96 \times 10^{-6} \mathrm{~mol} / \mathrm{L}$.

Figure 2 gives a summary of this constant-pH system. Sea life is very happy with the extra carbon dioxide in the atmosphere! $\left[\mathrm{CO}_{3}{ }^{2-}\right]$ grows linearly with $\left[\mathrm{CO}_{2}\right]$.

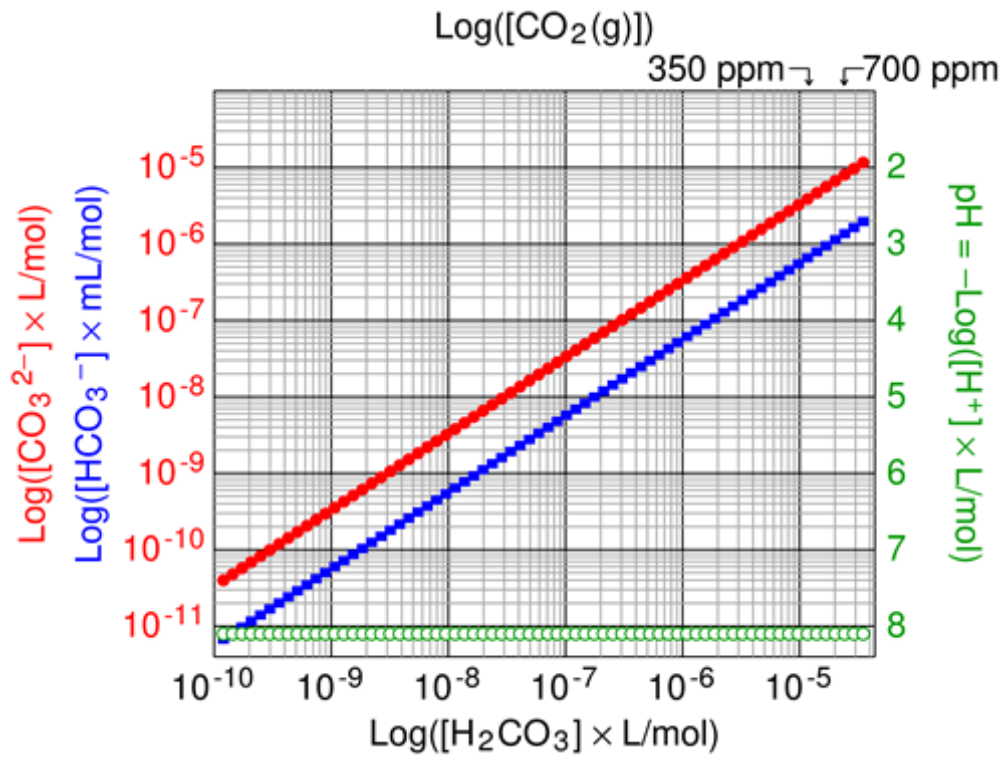

Figure 2: Concentration of carbonate ions ( $\bullet$ red full circles) bicarbonate ions ( $\square$ blue squares, $1000 \mathrm{x}$ scale) and $\mathrm{pH}$ ( $\circ$ green open circles) as a function of concentration of $\mathrm{CO}_{2}$ in the oceans and atmosphere for a buffered solution with constant $\mathrm{pH}$.

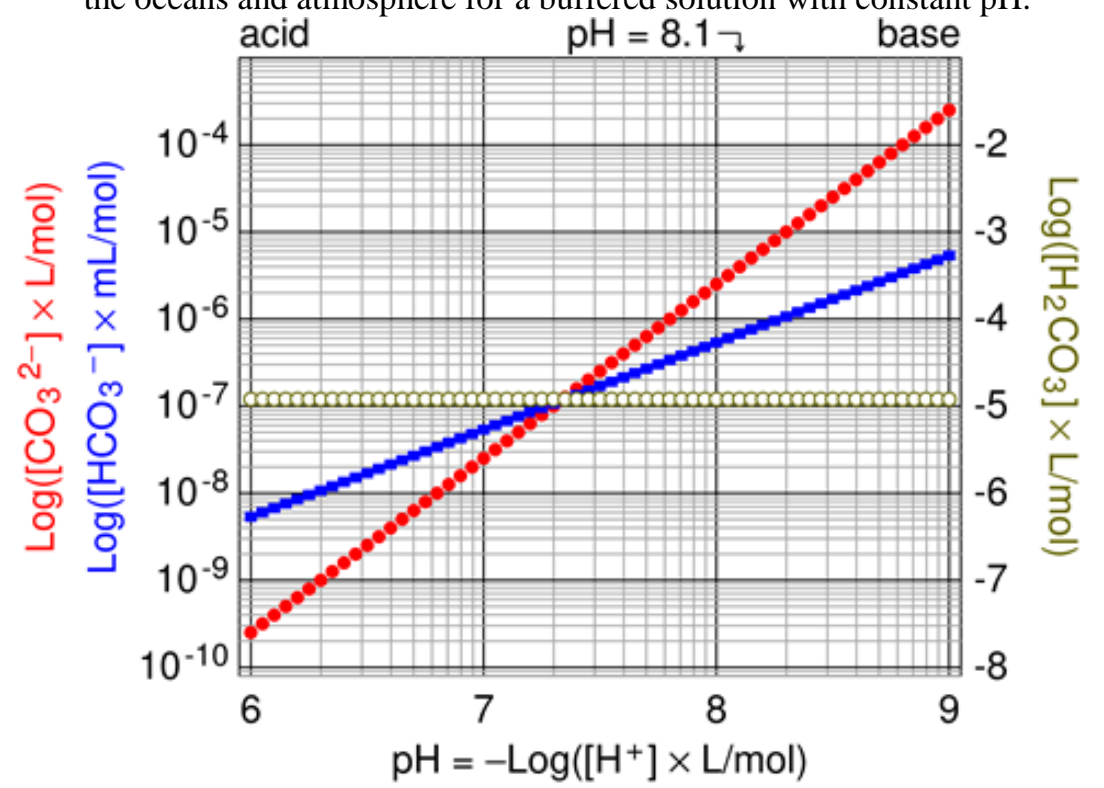

Figure 3: Concentration (as a function of $\mathrm{pH}$ ) of carbonate ions ( $\bullet$ red full circles) bicarbonate ions ( $\square$ blue squares, 1000x scale) and $\mathrm{H}_{2} \mathrm{CO}_{3}$ ( $\circ$ brown open circles) in the oceans below an atmosphere with (constant) $350 \mathrm{ppm}$ concentration $\mathrm{CO}_{2}$. 
Now let's repeat the above calculation for systems where not the carbon dioxide concentrations (in air and sea) change, but some other reaction produces hydrogen ions thereby changing the $\mathrm{pH}$ of the oceans (for instance raining sulphuric acid, creating $\mathrm{H}^{+}, \mathrm{HSO}_{4}{ }^{-}$and $\mathrm{SO}_{4}{ }^{2-}$ ) while the concentration of carbon dioxide above and in them remains the same. As can easily be shown, the end result is the same equation, Eq. 18. Figure 3 summarizes the effect of varying the $\mathrm{pH}$ (by other means than carbonic acid). Acids kill coral reefs.

It has to be noted that for these last calculations, the concentration of $\mathrm{CO}_{2}$ in the atmosphere (and $\mathrm{H}_{2} \mathrm{CO}_{3}$ in the oceans) is assumed to be constant. In many approaches the (chemistry) researchers make the logical error of assuming a constant carbon mass (following Lavoisier's principle) as often occurs in laboratory experiments, which are closed systems (for example test tubes). In this latter case the carbonate ion concentration can rise as well as fall for varying $\mathrm{pH}$. In the current analysis, the concentration in the atmosphere is a given fact (a parameter) and the rest results from simple chemistry equations as shown above.

Finally, we will show how for some specific cases of semidepleted buffers, the concentration of carbonate ions can decrease upon adding carbon dioxide in the oceans. To show this we have to simulate a real buffer with non-infinite resistance to $\mathrm{pH}$ changes. The first step is to create a buffer solution. We do this by adding a weak base molecule $\mathrm{B}$ to water (for instance $\mathrm{NH}_{3}$ ), that is a source of hydroxide ions by capturing a proton from water:

$$
\mathrm{B}\left(+\mathrm{H}_{2} \mathrm{O}\right) \rightleftharpoons \mathrm{BH}^{+}+\mathrm{OH}^{-},
$$

with a reaction constant given by

$$
K_{\text {buffer }}=\frac{\left[\mathrm{BH}^{+}\right]\left[\mathrm{OH}^{-}\right]}{[\mathrm{B}]} \text {. }
$$

We set this to $K_{\text {buffer }}=10^{-5.9} \mathrm{~mol} / \mathrm{L}$ so that the target $\mathrm{pH}$ will be 8.1 , as will be shown. In this solution $(C \mathrm{~mol} / \mathrm{L})$ we add an equal amount of salt BHS (for instance $\mathrm{NH}_{4} \mathrm{Cl}$ ) that is another source of conjugate acid ions,

$$
\mathrm{BHS} \rightleftharpoons \mathrm{BH}^{+}+\mathrm{S}^{-}
$$

We assume the reaction constant so large that effectively all salt is dissociated into ions and the negative ion concentration is equal to the original concentration of BHS added to the solution, $\left[\mathrm{S}^{-}\right]=C$. We thus have a total concentration of conjugated base molecule in solution equal to

$$
\left[\mathrm{BH}^{+}\right]=2 C-[\mathrm{B}]
$$


one contribution $(C)$ comes from the dissolved salt and the second contribution $(C-[\mathrm{B}])$ from the base that was protonated. Our chargeneutrality condition now becomes

$$
\left[\mathrm{H}^{+}\right]+\left[\mathrm{BH}^{+}\right]=\left[\mathrm{HCO}_{3}^{-}\right]+2 \times\left[\mathrm{CO}_{3}^{2-}\right]+\left[\mathrm{OH}^{-}\right]+\left[\mathrm{S}^{-}\right] .
$$

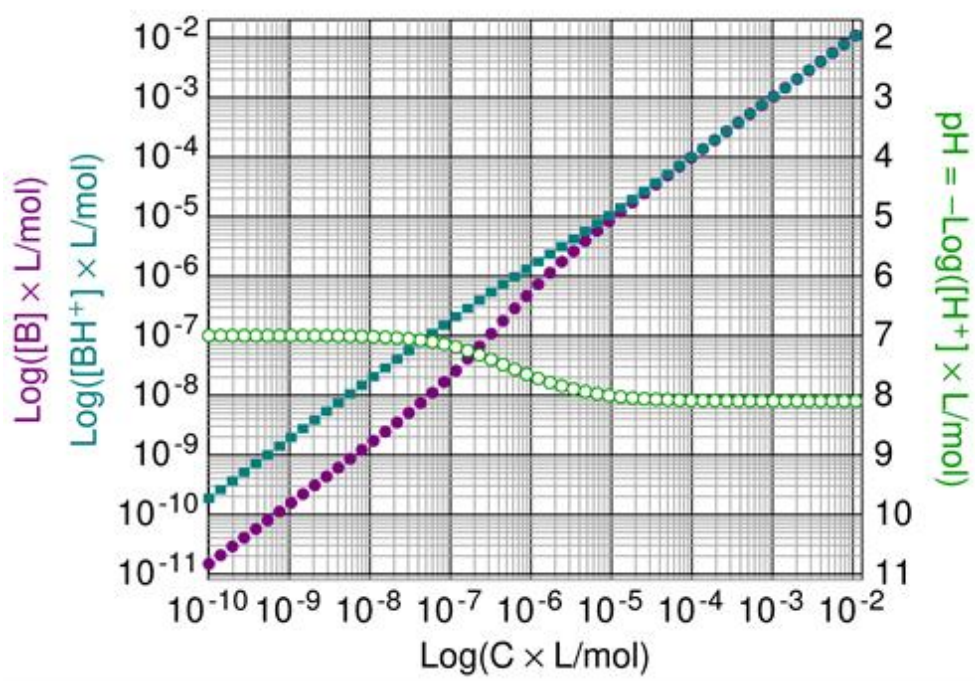

Figure 4: Concentration of base molecules ( $\bullet$ purple full circles) conjugated-acid ions ( cyan squares) and $\mathrm{pH}$ ( $\circ$ green open circles) as a function of $C$ equal to $\left[\mathrm{S}^{-}\right]$in a buffer solution without $\mathrm{CO}_{2}$.

This was combined with the $\mathrm{CO}_{2}$-related equations (Eqs. 15-17) and solved for various situations by the zero-finding bisection method described earlier. The first situation is one without any carbon, only varying the concentration of buffer ingredients $(C)$. This is shown in Figure 4 . We see that for increasing $C$ the $\mathrm{pH}$ settles at the target value 8.1 , there where the concentrations of base and conjugated acid become equal, $[\mathrm{B}]=\left[\mathrm{BH}^{+}\right]=C$. This figure is a confirmation of the Henderson-Hasselbalch equation, $\mathrm{pH}=14-\mathrm{p} K_{\text {buffer }}+$ $\log \left([\mathrm{B}] /\left[\mathrm{BH}^{+}\right]\right)$.

The next step is to vary the $\mathrm{H}_{2} \mathrm{CO}_{3}$ concentration in the ocean for various buffer solutions. 


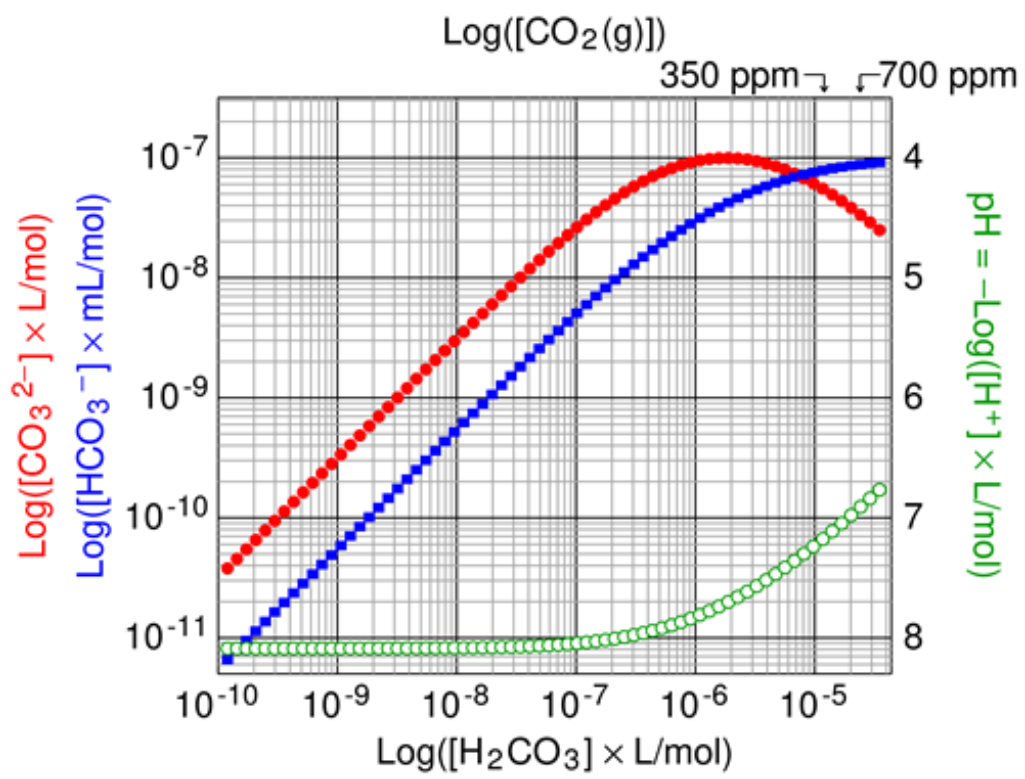

Figure 5: Concentration of carbonate ions ( $\bullet$ red full circles) bicarbonate ions $(\square$ blue squares, 1000x scale) and $\mathrm{pH}$ ( $\circ$ green open circles) as a function of concentration of $\mathrm{CO}_{2}$ in the oceans and atmosphere for a depleted buffer solution with $C=\left[\mathrm{S}^{-}\right]=10^{-4} \mathrm{~mol} / \mathrm{L}$.

For large values of $C$, for instance $C=1 \mathrm{~mol} / \mathrm{L}$, the constant-pH figure is reproduced (Figure 2). For small concentrations, for instance $C=10^{-8}$ $\mathrm{mol} / \mathrm{L}$, the pure-water figure is reproduced (Figure 1). However, for intermediate values of $C$, the behavior is (at first sight) peculiar in that for increasing carbon dioxide dissolved in the ocean, $\left[\mathrm{HCO}_{3}{ }^{-}\right]$rises in the ocean, following the principle of Le Châtelier, but $\left[\mathrm{CO}_{3}^{2-}\right]$ is dropping. See for instance Figure 5 for the case of $C=10^{-4} \mathrm{~mol} / \mathrm{L}$.

\section{Conclusions:}

In conclusion, we have shown here how increasing carbon dioxide in the atmosphere can indeed decrease the $\mathrm{pH}$ of the ocean - in principle even turn it acid - but in most cases adds the principal building ingredient of sea shells and coral reefs, carbonate ions. The effects range from completely zero (in the case of a pure ocean) to a linear increase in carbonate-ion density (in case of a buffered, constant $\mathrm{pH}$, environment). In intermediate-buffer cases some carbonate ions can be removed from the ocean by adding carbon dioxide. It shows how we should take care not to take rapid conclusions in thinking that any $\mathrm{pH}$ decrease will always destroy food for sea life. Things are a little more complicated than that.

\section{Disclosure of interests:}

The author declares not to have any conflict of interests. This research 
was paid by no grant. It received no funding whatsoever, apart from his salary at the university where he works. Nor is he member of any climate committees (political or other) or is he linked to companies or NGOs, financially or otherwise. He is not member of any political party or movement. This is an independent work that does not necessarily represent the opinion of his university or of his government. He wishes to thank Prof. Khmelinskii (UAlg) for valuable discussions.

\section{References:}

1. Essenhigh, R. H. (2009). Potential dependence of global warming on the residence time (rt) in the atmosphere of anthropogenically sourced carbon dioxide. Energy \& Fuels, 23, 2773-2784. doi:10.1021/ef800581r

2. Hoegh-Guldberg, O. (1999). Climate change, coral bleaching and the future of the world's coral reefs. Marine Freshwater Research, 50, 839-866. doi:10.1071/MF99078

3. Hoegh-Guldberg, O., Mumby, P. J., Hooten, A. J., Steneck, R. S., Greenfield, P., Gomez, E., . . Hatziolos, M. E. (2007). Coral reefs under rapid climate change and ocean acidification. Science, 318, 1737. doi:10.1126/science.1152509

4. Indermühle, A., Monnin, E., Stauffer, B., Stocker, T. F., \& Wahlen, M. (2000). Atmospheric $\mathrm{CO}_{2}$ concentration from 60 to $20 \mathrm{kyr}$ bp from the taylor dome ice core, Antarctica. Geophysical Research Letters, 27, 735-738.

5. Jacobson, M. Z. (2005). Studying ocean acidification with conservative, stable numerical schemes for nonequilibrium airocean exchange and ocean equilibrium chemistry. Journal of Geophysical Research, 110, D07302. doi:10.1029/2004JD005220

6. Kleypas, J. A., Buddemeier, R. W., Archer, D., Gattuso, J.-P., Langdon, C., \& Opdyke, B. N. (1999). Geochemical consequences of increased atmospheric carbon dioxide on coral reefs. Science, 284 ,

118-120. doi:10.1126/science.284.5411.118

7. Lide, D. R. \& Frederikse, H. P. R. (Eds.). (1974). CRC handbook of chemistry and physics $77^{\text {th }}$ edition. CRC Press.

8. Michaelidis, B., Ouzounis, C., Paleras, A., \& Pörtner, H. O. (2005). Effects of long-term moderate hypercapnia on acidbase balance and growth rate in marine mussels mytilus galloprovincialis. Marine Ecology Proress Series, 293, 109118. 
9. NOAA (2017). Ocean acidification. Retrieved November 10, 2017, from http://www.noaa.gov/resource-collections/oceanacidification

10. Press, W. H., Teukolsky, S. A., Vetterling, W. T., \& Flannery, B. P. (1989). Numerical recipes in pascal (first edition): the art of scientific computing. Cambridge University Press.

11. Royal Society (2005). Ocean acidification due to increasing atmospheric carbon dioxide. Clyvedon Press, Cardiff, U. K.

12. Silverman, J., Lazar, B., Cao, L., Caldeira, K., \& Erez, J. (2009). Coral reefs may start dissolving when atmospheric $\mathrm{CO}_{2}$ doubles. Geophysical Research Letters, 36, L05606. doi:10.1029/2008GL036282

13. Solomon, S., Qin, D., Manning, M., Chen, Z., Marquis, M., Averyt, K. B., . . Miller, H. L. (Eds.). (2007). IPCC, 2007: climate change 2007: the physical science basis. contribution of working group I to the fourth assessment report of the intergovernmental panel on climate change. Cambridge University Press.

14. Starr, C. (1992). Atmospheric $\mathrm{CO}_{2}$ residence time and the carbon cycle. Energy, 18, 1297-1310. doi:10.1016/03605442(93)90017-8

15. Ware, J. R., Smith, S. V., \& Reaka-Kudla, M. L. (1991). Coral reefs: 